\title{
Genetic Relationships of a Morphologically Unique Population of the Genus Eumeces (Scincidae: Squamata) from Iotorishima Island, Ryukyu Archipelago, as Revealed by Allozyme Data
}

\author{
JUNKO MOTOKAWA,${ }^{1 *}$ MASANAO TOYAMA,${ }^{2}$ AND TSUTOMU HIKIDA ${ }^{1}$
}

${ }^{1}$ Department of Zoology, Graduate School of Science, Kyoto University, Sakyo, Kyoto 606-8502, JAPAN

${ }^{2}$ Historiographical Institute, Okinawa Prefectural Archives, Arakawa 148-3, Haebaru, Okinawa 901-1105, JAPAN

\begin{abstract}
The Ryukyu five-lined skink, Eumeces marginatus, is an endemic species of the central and northern Ryukyus, and is composed of two morphologically defined subspecies, $E$. $m$. marginatus from the Okinawa Group, and $E$. $m$. oshimensis from the Amami and Tokara Groups. A population of the genus Eumeces, recently found on Iotorishima Island (an uninhabited islet located north of the main island chain of the Ryukyus), resembles $E$. $m$. oshimensis in having a relatively short median white line on the tail, but is distinct from any population of $E$. marginatus in having more midbody scale rows. To assess the taxonomic status of the Iotorishima population from a historical viewpoint, we examined its genetic relationships with $E$. marginatus populations. The degree of genetic differentiation between the Iotorishima population and a population of $E$. m. oshimensis from Tokunoshima, northern Amami islands, was fairly low $(D=0.043)$. Cluster analysis of genetic data also indicated that the Iotorishima population constitutes one of the two major clusters within $E$. marginatus together with four $E$. $m$. oshimensis populations from the northern Amami and southern Tokara islands. Thus, it is likely that the number of midbody scale rows in the Iotorishima population has increased rapidly after its relatively recent isolation. Taxonomically, the Iotorishima population seems to be most appropriately assigned to $E$. $m$. oshimensis.
\end{abstract}

Key words: Eumeces marginatus; Reptilia; Allozyme: Iotorishima Island; Ryukyu Archipelago

\section{INTRODUCTION}

Eumeces marginatus (Hallowell, 1861) is

* Corresponding author. Tel: +81-75-7534091; Fax: + 81-75-753-4114.

E-mail address: jun@zoo.zool.kyoto-u.ac.jp (J. Motokawa) a moderate-sized scincine lizard endemic to the Ryukyu Archipelago. The range of this species includes most islands of the Okinawa and Amami Groups, and 
Takarajima, Kodakarajima and Kojima Islands of the Tokara Group (Toyama, 1989; Ota et al., 1994). Two subspecies, $E$. $m$. marginatus from the Okinawa Group, and E. $m$. oshimensis from the Amami and Tokara Groups, are generally recognized on the basis of scutellation and coloration (e.g., Nakamura and Uéno, 1963). Although some external characters, such as the scale row number and juvenile tail coloration, are known to vary among island populations of $E$. marginatus, variations are not consistent with the geographic arrangement of populations and thus are considered to have little significance in terms of their historical relationships (Toyama, 1989). In fact, Kato et al. (1994), in the phylogenetic analyses of allozyme data for 19 populations representing six species of the East Asian Eumeces, recognized two assemblages of island populations within E. m. oshimensis, of which one is genetically closer to $E$. m. marginatus than to the other "consubspecific" assemblage.

Recently, Toyama (1995) reported on two Eumeces specimens collected for the first time from Iotorishima Island, an uninhabited islet $65 \mathrm{~km}$ west of Tokunoshima Island, the Amami Group (Fig. 1). These specimens, while most resembling $E$. $m$. oshimensis in head scutellation and coloration, differed from $E$. marginatus in having more rows of scales around the midbody (34, vs 24-30; Toyama, 1995).

In May 1997, four additional specimens of Eumeces were collected from Iotorishima Island by S. Ikehara and colleagues during a comprehensive scientific survey of the island. We sampled fresh tissues from

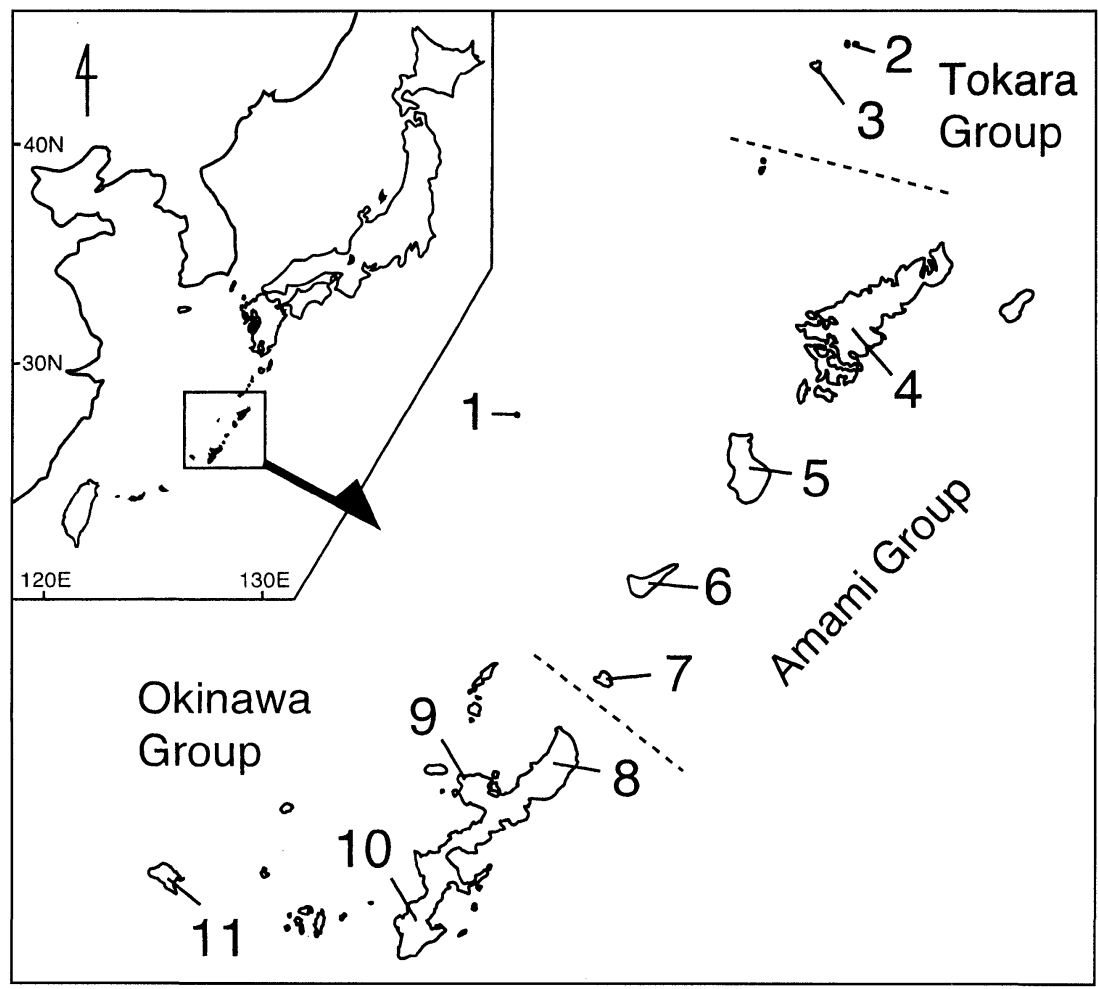

FIG. 1. A map of the central Ryukyus, showing sampling localities of Eumeces marginatus. 1=Iotorishima, 2=Kodakarajima, 3=Takarajima, 4=Amamioshima, 5=Tokunoshima, 6=Okinoerabujima, $7=$ Yoronjima, $8=$ Yona, $9=$ Bise, $10=$ Shuri, $11=$ Kumejima. 
these specimens, and examined them electrophoretically together with tissue samples of $E$. marginatus from almost whole of its range. Our purpose was to determine the taxonomic status of the Iotorishima population on the basis of its relationships with $E$. marginatus populations reflected by allozyme variations.

\section{MATERIALS AND METHODS}

We used four specimens from Iotorishima Island and 224 Eumeces marginatus specimens from eight islands of the Ryukyu Archipelago: the Tokara Group (Takarajima and Kodakarajima), the Amami Group (Amamioshima, Tokunoshima, Okinoerabujima, and Yoronjima), and the Okinawa Group (Okinawajima and Kumejima) (Fig. 1). All specimens from the same island, except for those from Okinawajima, were combined for the analyses under an a priori assumption that they represent a single randomly breeding population. Specimens from three localities within Okinawajima were treated as three separate samples, because the island's large size $(120 \mathrm{~km}$ in length, $10 \mathrm{~km}$ in breadth and $1200 \mathrm{~km}^{2}$ in area) may have enhanced subdivisions of its lizard population.

Homogenized tissue extracts were analyzed by horizontal starch gel electrophoresis. Sample preparation and electrophoretic procedures followed Shaw and Prasad (1970) and Harris and Hopkinson (1976) as modified by Kato et al. (1994). Enzymes examined and buffer systems used here were almost same as those in Kato et al. (1994). Nevertheless, Ah-2 (Kato et al., 1994) was excluded from the analyses, because products of this locus were not consistently clear enough to permit reliable scoring. Instead, peptidase was examined for the first time for the Japanese Eumeces, and resultant bands from liver extracts were interpreted as being controlled by a single locus, Pep-D. A total of 22 loci of 16 enzymes (i.e., Aat-1, Aat-2, Ada-2,
Ah-1, Ck-2, Est-4, Fh, Gdh, Gpi, Idh-1, Idh-2, Ldh-1, Ldh-2, Ldh-3, Mdh-1, Mdh2, Mpi, Pep-D, 6Pgdh-1, Pgm-1, Pgm-2, and Sod-1) were thus examined.

Allozyme data were treated as products of codominant alleles at a given locus. For some specimens of E. marginatus, allozyme data, taken from our previous study (Kato et al., 1994), were subjected to the analyses. All loci were evaluated for genetic polymorphism (mean number of alleles per locus, proportion of polymorphic loci, and observed mean heterozygosity). In order to estimate overall genetic differentiation among populations, Nei's (1978) unbiased genetic distance (D) was calculated on the basis of population allele frequencies. The resultant pairwise D matrix was further subjected to analyses by the UPGMA algorithm (Sneath and Sokal, 1973) for the purpose of estimating genetic relationships among populations. All computations were carried out using the BIOSYS-1 computer program (Swofford and Selander, 1981).

In addition, we quantified a few external characters (snout-vent length, tail length, extent of the median white line on tail, and the number of midbody scale rows), and also investigated the postnasal condition for the Iotorishima specimens.

\section{RESULTS}

Of the 22 presumptive loci analyzed, nine (Aat-2, Ck-2, Fh, Gdh, Ldh-1, Ldh-2, $\mathrm{Mpi}, \mathrm{Pgm}-1$ and Sod-1) were fixed in all samples. Allele frequencies at the other 13 polymorphic loci are given in Table 1 . At six of these (Idh-1, Idh-2, Ldh-3, Mdh-1, Mdh-2, and Pgm-2), the predominant (frequency of occurrence $>50 \%$ ) electromorph was identical in all samples. The Iotorishima sample had alleles common to the Tokunoshima sample at all loci, and all but the Est-4 locus were fixed or nearly fixed for these shared alleles. With respect to the latter locus, all of the Iotorishima specimens had a homozygote of an allele, 
TABLE 1. Allele frequencies at 13 polymorphic loci and variability estimates for 11 popoulations of Eumeces marginatus. Locality numbers correspond to those in Fig. 1. A=mean number of alleles per locus, $\mathrm{P}=$ percentage of polymorphic loci, $H=$ observed mean heterozygosity.

\begin{tabular}{|c|c|c|c|c|c|c|c|c|c|c|c|}
\hline \multirow[b]{2}{*}{ Locus } & \multicolumn{11}{|c|}{ Population (N) } \\
\hline & $1(4)$ & $2(18)$ & $3(12)$ & $4(19)$ & $5(21)$ & $6(22)$ & $7(22)$ & $8(30)$ & $9(31)$ & $10(24)$ & $11(25$ \\
\hline \multicolumn{12}{|l|}{ Aat-1 } \\
\hline a & & & & & & .886 & .952 & & .050 & .021 & \\
\hline $\mathrm{b}$ & 1.000 & 1.000 & 1.000 & 1.000 & 1.000 & .023 & & & .100 & .109 & \\
\hline $\mathrm{c}$ & & & & & & .091 & .048 & 1.000 & .850 & .870 & .320 \\
\hline $\mathrm{d}$ & & & & & & & & & & & .680 \\
\hline \multicolumn{12}{|l|}{ Ada } \\
\hline a & 1.000 & 1.000 & .958 & 1.000 & 1.000 & & & & & & \\
\hline $\mathrm{b}$ & & & .042 & & & & & .917 & .155 & .773 & 1.000 \\
\hline $\mathrm{c}$ & & & & & & 1.000 & 1.000 & .083 & .845 & .227 & \\
\hline \multicolumn{12}{|l|}{ Ah-1 } \\
\hline $\mathrm{a}$ & 1.000 & & & .053 & 1.000 & .955 & .977 & 1.000 & 1.000 & .861 & 1.000 \\
\hline $\mathrm{b}$ & & 1.000 & .958 & .921 & & .045 & .023 & & & .139 & \\
\hline $\mathrm{c}$ & & & .042 & .026 & & & & & & & \\
\hline \multicolumn{12}{|l|}{ Est-4 } \\
\hline $\mathrm{a}$ & & .028 & & & .025 & & & .038 & & & \\
\hline $\mathrm{b}$ & & .972 & 1.000 & 1.000 & .950 & .929 & .955 & & & & \\
\hline $\mathrm{c}$ & 1.000 & & & & .025 & .071 & .045 & .924 & .100 & .409 & .100 \\
\hline $\mathrm{d}$ & & & & & & & & .038 & .900 & .591 & .900 \\
\hline \multicolumn{12}{|l|}{ Gpi } \\
\hline $\mathrm{a}$ & 1.000 & & & & 1.000 & .045 & & & & & \\
\hline $\mathrm{b}$ & & 1.000 & 1.000 & 1.000 & & .955 & 1.000 & 1.000 & 1.000 & 1.000 & 1.000 \\
\hline \multicolumn{12}{|l|}{ Idh-1 } \\
\hline $\mathrm{a}$ & & & & & & & & .017 & & & \\
\hline $\mathrm{b}$ & 1.000 & 1.000 & 1.000 & 1.000 & .976 & 1.000 & 1.000 & .983 & 1.000 & 1.000 & 1.000 \\
\hline $\mathrm{c}$ & & & & & .024 & & & & & & \\
\hline \multicolumn{12}{|l|}{ Idh-2 } \\
\hline $\mathrm{a}$ & & & & & & & & & & .159 & \\
\hline $\mathrm{b}$ & 1.000 & 1.000 & 1.000 & 1.000 & 1.000 & 1.000 & 1.000 & 1.000 & 1.000 & .841 & 1.000 \\
\hline \multicolumn{12}{|l|}{ Ldh-3 } \\
\hline $\mathrm{a}$ & & & & & & & & & & .022 & .020 \\
\hline $\mathrm{b}$ & 1.000 & 1.000 & 1.000 & 1.000 & 1.000 & 1.000 & 1.000 & 1.000 & 1.000 & .978 & .980 \\
\hline \multicolumn{12}{|c|}{ Mdh-1 } \\
\hline $\mathrm{a}$ & 1.000 & 1.000 & 1.000 & 1.000 & 1.000 & 1.000 & 1.000 & 1.000 & 1.000 & 1.000 & .960 \\
\hline $\mathrm{b}$ & & & & & & & & & & & .040 \\
\hline \multicolumn{12}{|c|}{ Mdh-2 } \\
\hline $\mathrm{a}$ & & & & & & & & .086 & & & \\
\hline $\mathrm{b}$ & 1.000 & 1.000 & 1.000 & 1.000 & 1.000 & 1.000 & 1.000 & .880 & 1.000 & 1.000 & 1.000 \\
\hline $\mathrm{c}$ & & & & & & & & .034 & & & \\
\hline
\end{tabular}


TABLE 1. Extended

\begin{tabular}{ccccccccccccc}
\hline & \multicolumn{10}{c}{ Population (N) } \\
\cline { 2 - 10 } Locus & $1(4)$ & $2(18)$ & $3(12)$ & $4(19)$ & $5(21)$ & $6(22)$ & $7(22)$ & $8(30)$ & $9(31)$ & $10(24)$ & $11(25)$ \\
\hline Pep-D & & & & & & & & & & & \\
a & & & & & & & & .786 & .016 & & \\
b & 1.000 & 1.000 & 1.000 & 1.000 & 1.000 & 1.000 & .969 & .214 & .984 & 1.000 & 1.000 \\
c & & & & & & & .031 & & & & \\
6Pgdh-1 & & & & & & & & & & & \\
a & & & .083 & .059 & & & & & & & \\
b & 1.000 & 1.000 & .917 & .941 & 1.000 & .182 & .091 & 1.000 & 1.000 & .556 & 1.000 \\
c & & & & & & .818 & .909 & & & & \\
d & & & & & & & & & & .444 & \\
Pgm-2 & & & & & & & & & & & \\
a & & & & & & & .023 & & .016 & & .040 \\
b & 1.000 & 1.000 & 1.000 & 1.000 & 1.000 & 1.000 & .977 & .857 & .887 & 1.000 & .960 \\
c & & & & & & & & .143 & .097 & & \\
\hline A & 1.0 & 1.0 & 1.1 & 1.1 & 1.1 & 1.3 & 1.3 & 1.4 & 1.3 & 1.4 & 1.2 \\
(SE) & $(0.1)$ & $(0.0)$ & $(0.1)$ & $(0.1)$ & $(0.1)$ & $(0.1)$ & $(0.1)$ & $(0.1)$ & $(0.1)$ & $(0.1)$ & $(0.0)$ \\
P & 0.0 & 4.5 & 13.6 & 9.1 & 9.1 & 22.7 & 27.3 & 27.3 & 22.7 & 31.8 & 22.7 \\
H & 0.000 & 0.003 & 0.015 & 0.002 & 0.007 & 0.033 & 0.015 & 0.019 & 0.033 & 0.034 & 0.033 \\
(SE) & $(0.000)$ & $(0.003)$ & $(0.009)$ & $(0.002)$ & $(0.005)$ & $(0.016)$ & $(0.007)$ & $(0.011)$ & $(0.016)$ & $(0.013)$ & $(0.022)$ \\
\hline & & & & & & & & & & &
\end{tabular}

TABLE 2. Matrix of genetic distance (Nei, 1978) between 11 populations of Eumeces marginatus. A negative value set to -0.000 .

\begin{tabular}{lcccccccccc}
\hline Population & 1 & 2 & 3 & 4 & 5 & 6 & 7 & 8 & 9 & 10 \\
\hline 1. Iotorishima & - & & & & & & & & & \\
2. Kodakarajima & 0.145 & - & & & & & & & \\
3. Takarajima & 0.146 & -0.000 & - & & & & & & \\
4. Amamioshima & 0.141 & 0.000 & -0.000 & - & & & & & \\
5. Tokunoshima & 0.043 & 0.096 & 0.094 & 0.090 & - & & & & \\
6. Okinoerabujima & 0.223 & 0.174 & 0.167 & 0.166 & 0.175 & - & & & \\
7. Yoronjima & 0.243 & 0.188 & 0.181 & 0.180 & 0.191 & 0.000 & - & & \\
8. Yona & 0.182 & 0.233 & 0.230 & 0.229 & 0.231 & 0.196 & 0.210 & - & & \\
9. Bise & 0.174 & 0.179 & 0.177 & 0.174 & 0.178 & 0.108 & 0.122 & 0.095 & - & \\
10. Shuri & 0.162 & 0.168 & 0.163 & 0.163 & 0.183 & 0.126 & 0.139 & 0.059 & 0.034 & - \\
11. Kumejima & 0.182 & 0.186 & 0.182 & 0.181 & 0.185 & 0.161 & 0.174 & 0.090 & 0.053 & 0.036 \\
\hline
\end{tabular}

which occurred in very low frequency in the Tokunoshima sample.

In the present samples, values of the mean number of alleles per locus (A), proportion of polymorphic loci $(\mathrm{P})$, and observed mean heterozygosity per locus $(\mathrm{H})$ ranged from 1.0-1.4, 0.0-31.8, and 0.0000.034 , respectively (Table 1 ). The Iotorishima sample exhibited neither polymorphism nor allelic heterozygosity.

Pairwise comparisons of samples by Nei's (1978) genetic distance coefficient (D) 


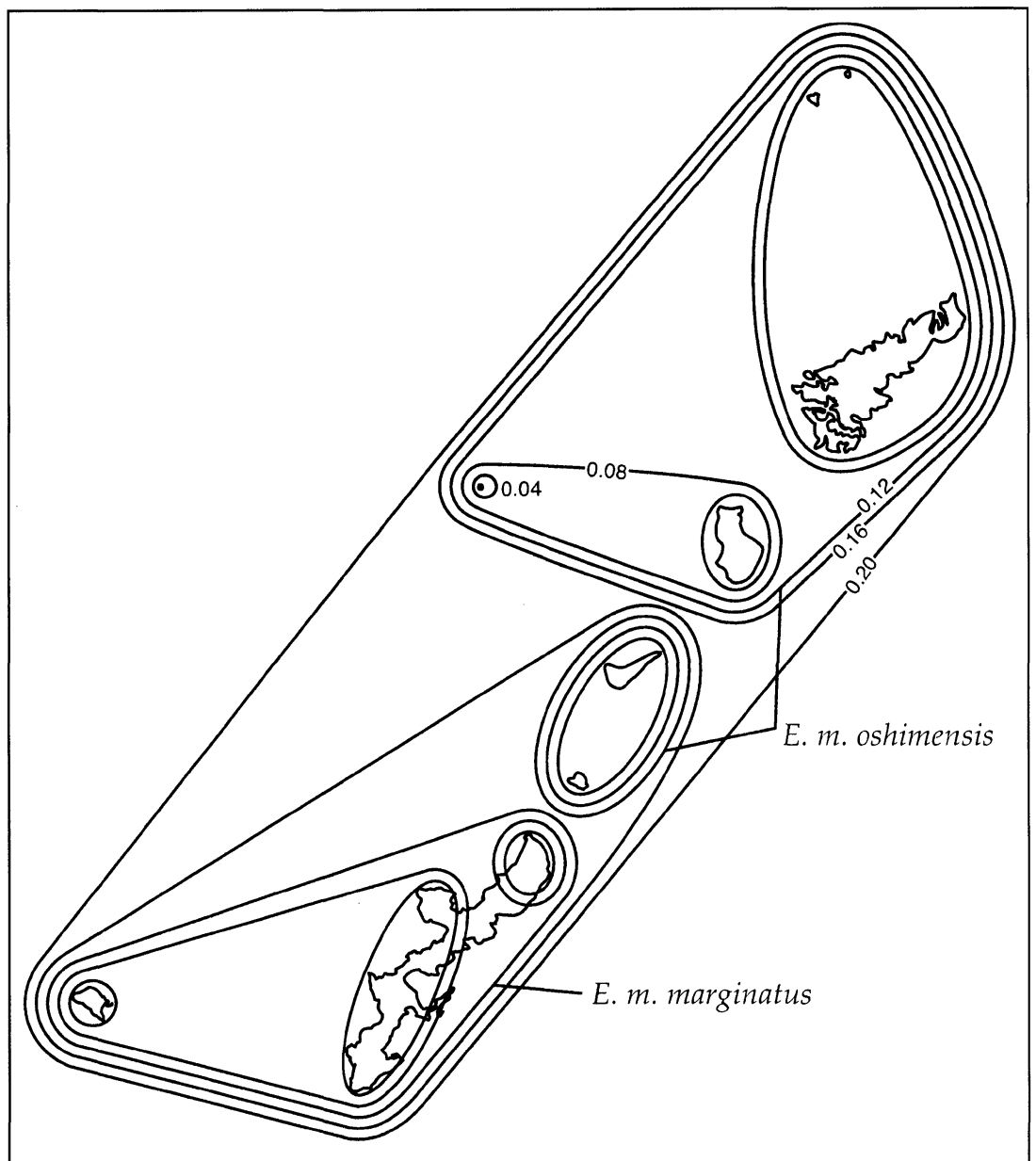

FIG. 2. Genetic relationships among 11 populations of Eumeces marginatus based on contours of Nei's (1978) genetic distance values derived from a UPGMA algorithm.

are presented in Table 2. The $\mathrm{D}$ value obtained between the Iotorishima and Tokunoshima samples was very small (0.043), whereas those of the former with other E. marginatus samples were larger (0.141-0.243).

Figure 2 shows genetic grouping of samples derived from the UPGMA clustering of pairwise $\mathrm{D}$ matrix. Populations currently assigned to $E$. $m$. marginatus were grouped together with high genetic similarities. By contrast, a great genetic heterogeneity was confirmed for $E$. $m$. oshimensis in the current delimitation, indi- cating a relatively distinct differentiation between the southern Amami and the northern Amami-southern Tokara assemblages, as reported previously (Kato et al., 1994). In this analysis, the Iotorishima sample was located in the cluster otherwise consisting of the northern Amami-southern Tokara E. m. oshimensis.

The four examined specimens from Iotorishima Island invariably had a medial white line not exceeding the proximal one third of the tail and 34 rows of midbody scales, and lacked the postnasal scale 
TABLE 3. Measurements (in $\mathrm{mm}$ ) and scale characters of the Ryukyu five-lined skink, Eumeces marginatus, from Iotorishima Island. $\mathrm{SVL}=$ snout-vent length, $\mathrm{TL}=$ tail length, $\mathrm{EL}=$ extent of the median white line on tail, $\mathrm{SR}=$ number of midbody scale rows, $\mathrm{PN}=$ postnasal condition.

\begin{tabular}{lccccccc}
\hline No. & Date of Collection & Sex & SVL & TL & EL & SR & PN \\
\hline KUZ34568 & 10 May 1997 & female & 48.6 & 89.4 & $>1 / 3$ & 34 & absent \\
KUZ34569 & 10 May 1997 & male & 51.5 & $15.2+*$ & $-* *$ & 34 & absent \\
KUZ34570 & 10 May 1997 & male & 49.3 & 89.1 & $>1 / 3$ & 34 & absent \\
KUZ34571 & 11 May 1997 & female & 48.8 & 87.1 & $>1 / 3$ & 34 & absent \\
\hline
\end{tabular}

$*:+$ tail broken.

**: - not clear.

(Table 3). These character states are identical to those in the two previously collected specimens reported by Toyama (1995).

\section{DISCUSSION}

Toyama (1995), in the description of external characters in the two previous specimens from Iotorishima Island, stated that their head scutellation seemingly fell within the range of variation in Eumeces marginatus. He further noted that in these specimens the extent of the median white line on the tail, a character used to discriminate the two subspecies of $E$. marginatus, was consistent with that of $E$. m. oshimensis rather than that of $E$. m. marginatus. However, he also noted that the specimens had many more rows of midbody scales (34) than E. marginatus (24-30). Examination of the four additional specimens confirmed these morphological characteristics for the Iotorishima population of Eumeces, and this alone may suggest a genealogical distinctness of this population from $E$. marginatus.

However, results of analyses of allozyme data indicate that the Iotorishima population is genetically remarkably similar to $E$. marginatus, and is much closer to the Tokunoshima population of E. m. oshimensis than any other consubspecific populations. This suggests an exclusively close historical affinity of the two populations, and we thus believe that the Iotorishima population should be classified as $E$. $m$. oshimensis, even though it exhibits a unique state in the number of midbody scale rows. It is probable that in such a small island population as that on Iotorishima Island the midbody scale rows have increased rapidly in response to selection pressure from some environmental factor there.

The Iotorishima population has alleles common to the Tokunoshima population at all loci and the $\mathrm{D}$ value between these populations was very small $(0.043)$. Such close genetic resemblance between the Iotorishima and Tokunoshima populations suggests that these populations have been very recently isolated. However, Iotorishima Island is situated $65 \mathrm{~km}$ west of Tokunoshima Island, and is separated from the latter, as well as from other islands having $E$. marginatus populations, by straits no less than $500 \mathrm{~m}$ in depth (MSAJ, 1978). Since sea level dropped by 120-140 m only during late Pleistocene (Ota et al., 1993), Iotorishima should have remained isolated then. The above result thus suggests a relatively recent overseas dispersal of the lizard between these islands. Otherwise, it necessitates an ad hoc assumption for the formation of a land bridge between them and its recent rapid submergence. 


\section{ACKNOWLEDGMENTS}

We wish to express our sincere thanks to M. Toda and Y. Obara, the members of the Iotorishima Scientific Survey Team organized by S. Ikehara, for providing us with invaluable specimens. We also thank H. Ota and M. Motokawa for giving us valuable comments on an earlier version of the manuscript.

\section{LITERATURE CITED}

HARRIS, H. AND D. A. HOPKINSON. 1976. Handbook of Enzyme Electrophoresis in Human Genetics. North-Holland Publ. Co., Amsterdam. (unpaged)

KATO, J., H. OTA, AND T. HikidA. 1994. Biochemical systematics of the Latiscutatus species-group of the genus Eumeces (Scincidae: Reptilia) from East Asian islands. Biochem. Syst. Ecol. 22(5): 491-500.

MSAJ (Maritime Safety Agency, Japan) (ed.) 1978. Depth Charts of East China Sea. Maritime Safety Agency, Japan, Tokyo. (unpaged)

NAKAMURA, K. AND S.-I. UÉNO. 1963. Japanese Reptiles and Amphibians in Color. Hoikusha, Osaka. 214 p. (in Japanese)

NEI, M. 1978. Estimation of average heterozygosity and genetic distance from a small number of individuals. Genetics 89(3): 583590.

Ota, H., N. SAKaguchi, S. IKehara, AND T. HIKIDA. 1993. The herpetofauna of the Sen- kaku Group, Ryukyu Archipelago. Pacific Sci. 47(3): 248-255.

OTA, H., M. TOYAMa, Y. Chigira, AND T. HIKIDA. 1994. Systematics, biogeography and conservation of the herpetofauna of the Tokara Group, Ryukyu Archipelago: new data and review of recent publications. WWF Japan Sci. Rep. 2(2): 163-177.

SHAW, C. R. AND R. PRASAD. 1970. Starch gel electrophoresis of enzymes-a compilation of recipes. Biochem. Genet. 4: 297-320.

SNeATH, P. H. A. AND R. R. SoKal. 1973. Numerical Taxonomy. W. H. Freeman, San Francisco. 573 p.

SwOFFord, D. L. AND R. B. SElANDER. 1981. BIOSYS-1: A FORTRAN program for the comprehensive analysis of electrophoretic data in population genetics and systematics. J. Hered. 72: 281-283.

TOYAMA, M. 1989. Distribution of the genus Eumeces (Scincidae: Lacertilia) in the Ryukyu Archipelago. p. 262-267. In: M. Matsui, T. Hikida, and R. C. Goris (eds.), Current Herpetology in East Asia. Herpetol. Soc. Japan, Kyoto.

TOYAMA, M. 1995. On the skink of the genus Eumeces from Iotorishima Island, the Ryukyu Archipelago. Akamata 11: 5-6. (in Japanese)

Accepted: 15 May 2001 